\title{
cGMP Signaling in the Cardiovascular System-The Role of Compartmentation and Its Live Cell Imaging
}

\author{
Nadja I. Bork ${ }^{1,2}$ and Viacheslav O. Nikolaev ${ }^{1,2, *}$ \\ 1 Institute of Experimental Cardiovascular Research, University Medical Center Hamburg-Eppendorf, \\ University of Hamburg, Hamburg 20246, Germany; n.bork@uke.de \\ 2 German Center for Cardiovascular Research (DZHK), Partner site Hamburg/Kiel/Lübeck, \\ Hamburg 20246, Germany \\ * Correspondence: v.nikolaev@uke.de; Tel.: +49-40-7410-51391
}

Received: 31 January 2018; Accepted: 7 March 2018; Published: 10 March 2018

\begin{abstract}
The ubiquitous second messenger $3^{\prime}, 5^{\prime}$-cyclic guanosine monophosphate (cGMP) regulates multiple physiologic processes in the cardiovascular system. Its intracellular effects are mediated by stringently controlled subcellular microdomains. In this review, we will illustrate the current techniques available for real-time cGMP measurements with a specific focus on live cell imaging methods. We will also discuss currently accepted and emerging mechanisms of cGMP compartmentation in the cardiovascular system.
\end{abstract}

Keywords: cGMP; cardiovascular system; imaging; FRET; compartmentation

\section{1. cGMP Signaling in the Cardiovascular System}

The ubiquitous second messenger cyclic guanosine $3^{\prime}, 5^{\prime}$-monophosphate (cGMP) plays an important role in the cardiovascular system [1-4]. Since its discovery more than 50 years ago [5], a lot of research has been done on cGMP signaling which still represents an actively studied topic [6]. In the cardiovascular system, cGMP signaling is essential to several cell types, including cardiomyocytes (CMs), vascular smooth muscle cells (VSMCs), endothelial cells (ECs), and cardiac fibroblasts (CFs) [1,7-10].

\section{1. cGMP Synthesis}

cGMP is generated from guanosine triphosphate (GTP) by specialized enzymes called guanylyl cyclases (GCs). There are at least two different pathways for cGMP formation-one stimulated by nitric oxide (NO) and another triggered by natriuretic peptides (NPs) [11,12].

In mammalian cells and tissues, GCs exist in two different forms. The soluble guanylyl cyclase (sGC) is a haem-containing enzyme, consisting of two subunits ( $\alpha$ and $\beta$, the latter contains a haem binding domain). The particulate guanylyl cyclase (pGC) is a single-chain haem-free transmembrane protein. Both GCs are involved in cGMP signaling [12-15]. sGCs are stimulated by NO [16-18], whereas pGCs are stimulated by NPs $[19,20]$.

There are at least seven pGCs (GC-A to GC-G). However, thus far, ligands for only three of them (GC-A, GC-B, and GC-C) have been identified, whereas the other pGCs are supposed to act as orphan receptors $[19,21]$. Atrial natriuretic peptide (ANP) and brain natriuretic peptide (BNP) are the natural ligands for GC-A. C-type natriuretic peptide (CNP) is the ligand for GC-B [9,21-24]. pGCs are localized to cell membranes [25].

sGC consists of two subunits and is typically found as a heterodimer composed of a larger $\alpha$ subunit and a smaller $\beta$ subunit. sGC $\alpha_{1} \beta_{1}$ heterodimer is the most prevalent sGC isoform, although homodimers of these subunits can also be formed $[1,13,15,26]$. Indeed, sGC has also been shown 
to be targeted to caveolin-rich membrane domains together with NO-producing synthases (NOS). For example, the co-localization with caveolin-1 [27], heat shock protein 90, and endothelial NO synthase (eNOS) was demonstrated in aortic ECs [28], as well as the membrane association of sGC $\alpha_{2} \beta_{1}$ in rat brain [14].

cGMP concentrations can be also modulated by stimulation with acetylcholine (ACh). There are two major types of ACh receptors (AChRs), the muscarinic AChRs (mAChRs) and the nicotinic AChRs (nAChRs). [29-31]. ECs, smooth muscle cells, as well as CMs are known to express both, mAChRs and nAChRs [32-37]. Studies in the early 1990s could already show that stimulation of blood vessels with ACh leads to an endothelium-dependent relaxation of the vascular smooth muscle which is mediated through the formation of an endothelium derived relaxing factor (EDRF) which has been identified as NO $[38,39]$. EDRF can be produced by NOS enzymes in ECs upon ACh stimulation of the muscarinic $\mathrm{M}_{3}$ receptors, this pathway leads to an increase cGMP levels of vascular smooth muscle by stimulation of sGC [40-42]. In the heart, muscarinic $\mathrm{M}_{2}$ receptors expressed in atrial CMs play a crucial role in the regulation of heart rate and arhythmogenesis [43], which is mediated by ventricular CMs, since they are partially innervated by the parasympathetic nervous system [44]. Interestingly, nAChRs are also expressed in myocardium and can mediate protection of the heart from ischemia reperfusion injury [45].

\section{2. cGMP Effector Activation}

There are at least three classes of presently known cGMP effector proteins. First, cGMP-dependent protein kinases (PKGs, also known as cGKs), are important downstream targets of cGMP in the cardiovascular system. Three PKG isoforms have been identified (PKG-type I $\alpha$ (PKG I $\alpha$ ), PKG-type I $\beta$ (PKG I $\beta$ ), and PKG-type II (PKG II)), whereby PKG I $\alpha$ and PKG I $\beta$ are splice variants originating from alternative splicing of one single gene. In the cardiovascular system, PKG I is the major isoform-PKG I $\alpha$ and PKG I $\beta$ are expressed in VSMCs-while ECs express PKG I $\beta$, and CMs express PKG I $\alpha[1,26,46-50]$. Second, cyclic nucleotide-gated (CNG) channels, nonselective cation channels, can be activated by the binding of cGMP or cyclic adenosine $3^{\prime}, 5^{\prime}$-monophosphate (cAMP). They play a central role in the signal transduction pathways of vision and olfaction, as well as in the regulation of sinus node function and cardiac pacemaking [51-53]. Finally, activity of some phosphodiesterases (PDEs) can be regulated by cGMP as described below.

\section{3. cGMP Catabolism by Phosphodiesterases}

Cyclic nucleotide PDEs hydrolyze cyclic nucleotides, e.g., cGMP and cAMP to inactive monophosphates guanosine monophosphate (GMP) and adenosine monophosphate (AMP), respectively. Therefore, they are involved in the regulation of the cellular levels of the second messengers cAMP and cGMP [13,25,50,54-56].

At least 21 genes encoding for PDEs have been described. PDEs can be subdivided into 11 families (PDE1-PDE11) [57,58]. In the heart, seven PDE families have been investigated (PDE1, PDE2, PDE3, PDE4, PDE5, PDE8, and PDE9). While PDE1, PDE2, PDE3, PDE10, and PDE11 are dual-substrate specific and can hydrolyze both cAMP and CGMP, PDE4, PDE7 and PDE8 are specific for cAMP, whereas PDE5, PDE6 and PDE9 can only hydrolyze cGMP. Dual-substrate specific PDEs, especially PDE2 and PDE3 lead to a crosstalk between cAMP and CGMP. PDE3 primarily hydrolyzes cAMP ( $\mathrm{V}_{\max }$ for cAMP 4-10 times higher than for cGMP [59]), but can be competitively inhibited by cGMP. Therefore, it is often referred to as the cGMP-inhibited PDE. In that way, increasing cGMP concentrations (which inhibit PDE3) can increase cAMP levels leading to the so-called positive cGMP-to-cAMP cross-talk. PDE2 can be allosterically activated by cGMP and therefore, an increase in cGMP level can negatively regulate cAMP levels via PDE2, creating the so-called negative cGMP-to-cAMP cross-talk [54,59-62]. 


\section{Live Cell Imaging of cGMP}

Since a lot of research is done on cGMP signaling, the development of techniques to measure cGMP concentrations in living cells and tissues has become essential. Up to now, several techniques to measure cGMP concentrations have been developed and applied in numerous studies $[6,63,64]$ (Table 1).

Traditional biochemical methods such as immunohistochemistry [65], radioimmunoassays, enzyme-linked immunoassays (ELISA) [66,67] or Western blot analysis [64] are quite sensitive and specific methods to detect cGMP or its downstream effector function. However, they all represent cell-destructive type of assays which can measure only total cGMP levels with low spatial resolution instead of physiologically relevant free cGMP localized in subcellular microdomains. In addition, they often require PDE inhibition to obtain adequate sensitivity, thereby ignoring tight regulation of local cGMP by these enzymes [64,68]. In sharp contrast, development of real-time detection methods during the last two decades has enabled studies of cyclic nucleotide dynamics and compartmentation in living cells with high temporal and spatial resolution in real time [64] (Table 1).

The first real-time detection of cGMP in living cells was done by electrophysiological recordings of CNG ion channels. For their experiments, Trivedi and Kramer [69] used an exogenously expressed CNG channel that was engineered to be especially sensitive and selective for cGMP in neoblastoma cells $[69,70]$. CNG measurements were also used in adult rat CMs [71]. For this purpose, the rat olfactory CNG channel $\alpha$-subunit was expressed in adult rat CMs, and recordings of the respective cGMP-gated current $\left(\mathrm{I}_{\mathrm{CNG}}\right)$ was done $[69,71]$. The use of CNG channels for live cell measurements offers the advantage of high temporal resolution. However, electrophysiological measurements are technically challenging and time consuming and their temporal resolution is rather limited to subsarcolemmal microdomains [72].

Förster resonance energy transfer (FRET) microscopy has become a useful tool to monitor and quantify real-time dynamics of protein-protein interactions and biochemical processes [73]. FRET is the radiationless transfer of excited-state energy from an initially excited fluorescent donor to an acceptor fluorophore molecule [74-76]. Up to now, several FRET sensors to measure cGMP dynamics have been described and used in multiple cell types (Table 1).

Table 1. Techniques to measure cGMP in living cells and tissues.

\begin{tabular}{|c|c|c|}
\hline Method & Advantages/Disadvantages & References \\
\hline $\begin{array}{l}\text { Traditional biochemical methods } \\
\text { Immunohistochemistry } \\
\text { Radioimmunoassays } \\
\text { Enzyme-linked immunoassays } \\
\text { Immunoblots for PKG substrate } \\
\text { phosphorylation }\end{array}$ & $\begin{array}{c}\text { Quite sensitive and specific } \\
\text { Cell destructive assays } \\
\text { Only measure total cGMP levels } \\
\text { Often require PDE inhibition to obtain } \\
\text { adequate sensitivity }\end{array}$ & [64-67] \\
\hline \multicolumn{3}{|l|}{ Real-time cGMP detection } \\
\hline $\begin{array}{l}\text { Electrophysiological recordings of } \\
\text { CNG ion channels }\end{array}$ & $\begin{array}{c}\text { High temporal resolution } \\
\text { Technically challenging and time consuming } \\
\text { Temporal resolution limited to } \\
\text { subsarcolemmal microdomains }\end{array}$ & [69-71] \\
\hline $\begin{array}{c}\text { Förster resonance energy transfer } \\
\text { (FRET) based cGMP sensors } \\
\text { CGY-Del1 } \\
\text { Cynget-1/2 } \\
\text { cGES-DE2/5 } \\
\text { cGi-500/3000/6000 } \\
\text { red cGES-DE5 }\end{array}$ & $\begin{array}{c}\text { High temporal and spatial resolution } \\
\text { Sensitivity for cGMP measurements in some cell } \\
\text { types challenging } \\
\text { cGMP/cAMP selectivity important }\end{array}$ & $\begin{array}{c}{[77,78]} \\
{[68,79]} \\
{[77,80]} \\
{[81-83]} \\
{[63,84,85]}\end{array}$ \\
\hline $\begin{array}{l}\text { Non-FRET based cGMP sensors } \\
\text { FlincG1-3 }\end{array}$ & $\begin{array}{c}\text { Good cGMP sensitivity } \\
\text { Relatively low cGMP/cAMP selectivity }\end{array}$ & {$[86,87]$} \\
\hline
\end{tabular}


The sensor CGY-Del1 was one of the first cGMP sensors developed for FRET imaging. It consists of tandem fusion proteins of enhanced cyan (ECFP), PKG I $\alpha_{\Delta 1-47}$, and enhanced yellow fluorescent protein (EYFP). However, despite very good sensitivity (cGMP EC 50 value of $20 \mathrm{nM}$ ), it has a low cGMP/cAMP selectivity and is not usable in adult CMs which have high cAMP levels [77,78]. Another cGMP FRET sensor developed at the same time was the Cynget- $1 / 2$ sensor. It consists of a PKG (with N-terminally deleted residues 1-77), flanked between cyan and yellow fluorescent proteins. With a much better cGMP/cAMP selectivity than the CGY-Del1 sensor, this sensor has been used in neonatal CMs, however it is not usable in adult CMs due to a very low sensitivity $\left(\mathrm{EC}_{50}=1.5 / 1.9 \mu \mathrm{M}\right)[68,79]$. The use of these sensors (CGY and Cygnets) is limited by either low specificity or sensitivity and low temporal resolution [77].

Two other types of cGMP FRET sensors with faster kinetics and moderate cGMP/cAMP selectivity have been developed based on CGMP binding regulatory domains of PDEs or CGMP binding domains of PKG. One is the cGES-DE2/5 FRET sensor. It consists of a PDE2A GAF-B domain or PDE5A GAF-A domain fused to ECFP and EYFP $[77,80]$. Another group of constructs are the cGi-FRET sensors (cGi-500/3000/6000). In these sensors, both cGMP-binding domains from PKG I are sandwiched between ECFP and EYFP [81-83]. However, with cGMP EC C0 $_{50}=0.9 / 1.5 \mu \mathrm{M}$ for cGES-DE2 $/ 5$, and cGMP $\mathrm{EC}_{50}=500 / 3000 / 6000 \mathrm{nM}$ for cGi-500/3000/6000 (cAMP EC 50 values are in the range of 100-500 $\mu \mathrm{M}$ ), neither is optimal for adult CMs because of relatively low sensitivity.

Because of very low cGMP concentrations in adult CMs, reliable cGMP measurements in these cells have been challenging in the past [63]. With the development of the red cGES-DE5 FRET sensor, consisting of a single cGMP-binding (GAF-A) domain from PDE5 fused to the fluorophores T-Sapphire and Dimer2 and an $\mathrm{EC}_{50}$ of $\sim 40 \mathrm{nM}$, cGMP FRET measurements in adult CMs became possible $[63,84,85]$.

It is important to mention that there is also a non-FRET type of cGMP sensors called FlincG1-3, which can be used for cGMP measurements as well. FlincGs are composed of both cGMP binding domains from PKG I fused to a circularly permuted GFP. However, despite a good sensitivity for cGMP with $\mathrm{EC}_{50}=0.17-0.89 \mu \mathrm{M}$, they have a relatively low cGMP/cAMP selectivity $[86,87]$ (Table 1$)$.

\section{Compartmentation of cGMP Signaling in the Cardiovascular System}

Caused by the lack of real-time cGMP detection methods in the past, spatial localization of the cGMP signaling pathway components has long been poorly studied [6]. However, with the development of methods for real-time cGMP detection, it became possible to analyze cGMP compartmentation in intact cells of the cardiovascular system.

\subsection{Compartmentation in Cardiomyocytes}

In CMs, cGMP signaling is involved in the regulation of contractility [1]. Various studies have been done, investigating the effects of NP/pGC/cGMP- and NO/sGC/cGMP-pathways on CM contractility.

CNP was shown to have a direct positive chronotropic [88] and dromotropic [89] effect in anaesthetized dogs. Studies in cultured neonatal rat CMs showed negative inotropic effects caused by CNP stimulation $[90,91]$. In rat papillary muscles, CNP exerted a positive lusitropic and a negative inotropic effect [92]. In isolated working mouse hearts, CNP exerted positive inotropic and lusitropic effects $[93,94]$, followed by a delayed negative inotropic action [93].

ANP effects on CM contractility seem to be less clear. Some studies could show that ANP decreases contractility in isolated CMs $[95,96]$, whereas in other studies no effect of ANP on cardiac mechanical function could be detected [89,92]. One study showed that ANP has no direct effects on cardiac contractility in isolated working mouse hearts, but the chronic absence of its receptor, GC-A, results in increased responsiveness to CNP [93].

The effect of NO on the heart has also been investigated by various groups. While some studies found a negative inotropic effect of NO donors on force contraction in human atrial and ventricular myocardium [97] and in isolated adult rat ventricular CMs [98], other studies could not observe any 
effects of NO donors in isolated cat and rat papillary muscles [99], or in atrial myocardium preparations from rats, rabbits, guinea pigs, frogs, and humans [100].

One possible explanation for the different effects of NO donors in different studies was given by Wegener et al. [101]. They showed that, in atrial and ventricular muscle strips, myoglobin acts as intracellular scavenger of $\mathrm{NO}$, preventing $\mathrm{NO}$ from reaching its intracellular receptors in CMs. Therefore, the different NO effects seem to be-at least in part-dependent on the myoglobin concentration in the particular preparations [101].

In 2006, a cell-based study provided the first evidence that the cGMP signaling pathways are compartmentalized [71]. It was already known before from a previous report which used frog ventricular myocytes to study the modulation of $\mathrm{I}_{\mathrm{Ca}}$ by NO donors, that the NO-mediated signaling remains in the local environment and is closely associated with local cAMP concentrations, implying the formation of signaling microdomains [102]. The group around Rodolphe Fischmeister [71] tested whether the different effects of NPs and NO donors on cardiac and vascular smooth muscle function are due to an intracellular compartmentation of cGMP. In rat CMs, they monitored subsarcolemmal cGMP signals by ectopically expressed rat olfactory CNG channel $\alpha$ subunit and real-time recordings of the associated cGMP-gated current $\left(\mathrm{I}_{\mathrm{CNG}}\right)$. They could show that in rat $\mathrm{CMs}$, the particulate (ANP-stimulated) cGMP pool is readily accessible at the plasma membrane, whereas the soluble (NO donor-stimulated) pool is not. Additionally, they showed that PDE5 controls the soluble but not the particulate pool, whereas the latter is under the exclusive control of PDE2 (Figure 1) [71,103]. However, the study did not examine whether this compartmentation resulted in different PKG and/or cellular functional response.

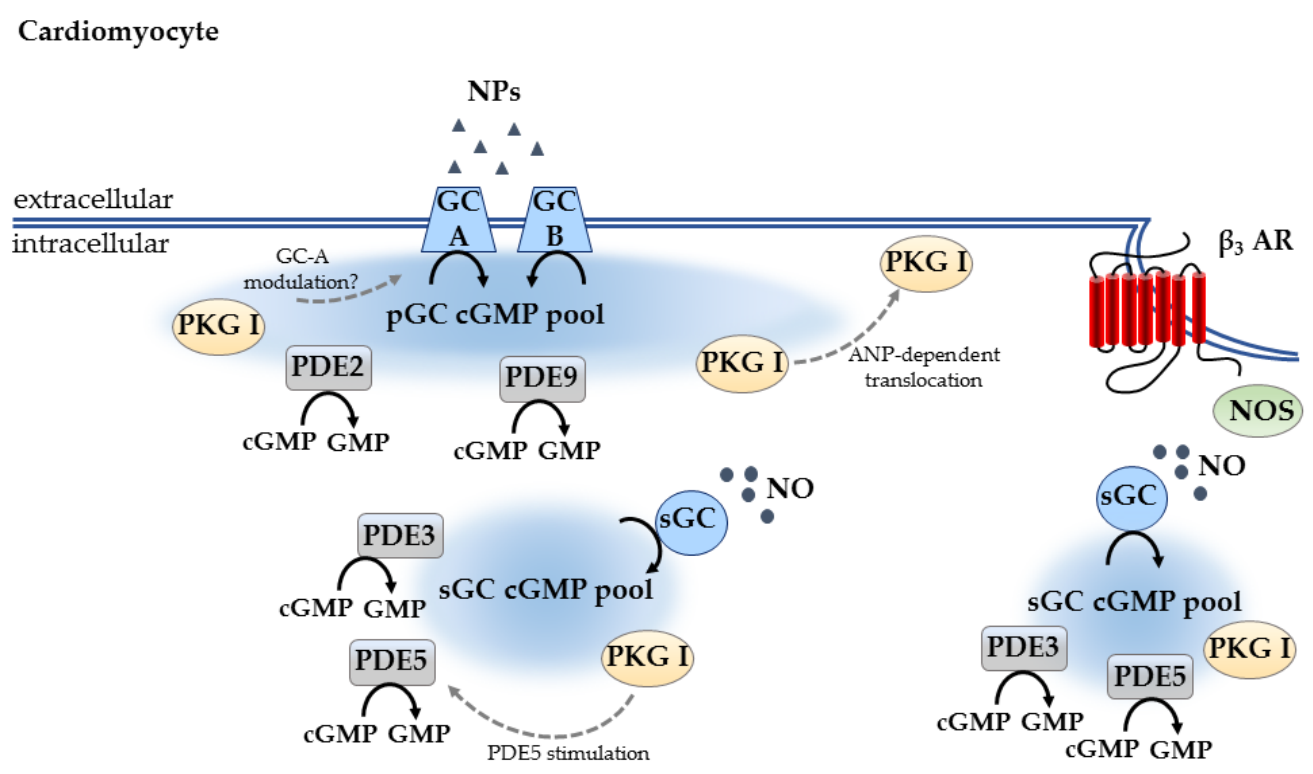

Figure 1. cGMP compartmentation in CMs. There are at least two different cGMP pools: the NP/pGC/ cGMP pool formed at the plasma membrane, and the NO/sGC/cGMP pool which can be controlled by the $\beta_{3}$-adrenergic receptor $\left(\beta_{3}-\mathrm{AR}\right)$ at the cell surface caveolae. pGC/cGMP is tightly controlled by PDE2 and PDE9, while sGC/cGMP pool is predominantly regulated by PDE5 and PDE3. PKG I is one of the major downstream targets for cGMP signaling. NO/sGC stimulated PKG I is known to phosphorylate and inhibit PDE5. ANP/pGC stimulated PKG I can be recruited to the plasma membrane and is assumed to modulate GC-A activity. Black arrows indicate enzymatic activity, dotted arrows indicate protein action.

The effect of PKG on the different cGMP pools generated by pGC and sGC was investigated some years later. In adult CMs, it was shown that PKG activation limits the accumulation of cGMP induced by NO donors (via PDE5 stimulation) but increases that induced by NPs (by a still unknown 
mechanism, possibly by PKG-dependent modulation of GC-A). This indicates that PKG, via a feedback control, is one of the key components in the modulation of subcellular microdomains [104].

There are also some hints that PKG is recruited to the plasma membrane, even though such studies have not been done in CMs yet. It could be shown in a yeast two-hybrid system, that PKG can directly interact with GC-A. In human embryonic kidney cells expressing GC-A, it is recruited to the plasma membrane following ANP treatment. In this system, PKG translocation was ANP-dependent but not NO dependent [105]. The same effect could also be shown in rat hepatocytes where ANP promotes plasma membrane recruitment of PKG I $\alpha$ through localized cGMP elevation [106].

Another study examined the functional significance of such cellular compartments which were found by Liliana Castro and colleagues [71]. In an in vivo study, Takimoto and colleagues could show that the regulation of cardiac $\beta$-adrenergic response by cGMP is linked to a NO-synthesis/ PDE5-hydrolyzed pool signaling via PKG. In contrast to that, NP stimulation achieved greater detectable increases in cGMP but not PKG activity and did not modulate $\beta$-adrenergic response [107].

It was already known from cardiac function studies in adult mice that PDE5 regulation of the adrenergic response depends upon NOS-induced cGMP/PKG and can be enhanced by sustained low-level stimulation of SGC [108]. To investigate the cellular mechanisms for the modulation of the $\beta$-adrenergic response by PDE5 inhibition, another study was done in adult mouse CMs. The authors examined the role of PDE2 and PDE3, $\beta_{3}$-adrenergic signaling, and PKG targeting of the contractile apparatus for modulation of $\beta$-adrenergic response by PDE5 inhibitors. They could show that anti-adrenergic effects of PDE5A inhibition are not modulated by PDE2 or PDE3, but rather require $\beta_{3}$-AR stimulation and PKG activation with a subsequent Troponin I phosphorylation [109].

With the development of the red cGES-DE5 FRET sensor it became possible to perform FRET measurement in adult mouse CMs. Studies in transgenic mice with CM-specific expression of this cytosolic FRET biosensor showed that PDE3 is the main PDE responsible for cytosolic cGMP degradation [63]. In 2015, a study was presented which investigated the involvement of cGMP degrading PDE9 in the heart [110]. The role of PDE5 as regulator of NO-generated cGMP was already known [103], however PDEs controlling NP-generated cGMP were still uncertain at this time. The authors could show that in adult mouse hearts and in isolated CMs, PDE9 regulates NP- rather than NO-stimulated cGMP [110] (Figure 1).

Despite these several studies investigating cGMP compartmentation in CMs, yet there are still many unresolved questions. For further studies of cGMP microdomains in adult CMs, targeted cGMP FRET sensors-like those which already exist for cAMP [111,112]-would be especially useful.

\subsection{Compartmentation in Other Cell Types}

\subsubsection{Compartmentation in Vascular Smooth Muscle Cells}

In VSMCs, cGMP signaling is involved in cell proliferation and differentiation [1,113]. VSMCs are the contractile cells of the blood vessels including the coronary arteries and veins [47] and it could be shown that the NO/cGMP signaling cascade plays an essential role in vascular smooth muscle relaxation $[114,115]$.

In 2006, a study could show that several differences might exist between cGMP signaling in CMs and VSMCs. The authors investigated the subcellular localization of cGMP signals by measuring CNG channel activity in response to agonists for either pGC or sGC in human embryonic kidney cells expressing GC-A as well as in VSMCs. They could show that cGMP signals are spatially segregated and that the functional compartmentation of cGMP signals may underlie the unique actions of ANP and NO [116]. Comparing the results from this study with the study from Castro et al. [71], it becomes obvious that, in VSMCs, the relative increase in cGMP with NO-sGC stimulation exceeded that with NP-pGC [116], which is the opposite to what was observed in CMs [71].

In another study, it was shown by the use of the cGMP-biosensor FincGs that, in unpassaged adenoviral transfected VSMCs, global cGMP elevation was created to NO response. In contrast, 
local sub-membrane elevations were generated in response to ANP, which were converted to global, more diffused ones after PDE5 inhibition [87] (Figure 2).

Vascular smooth muscle cell

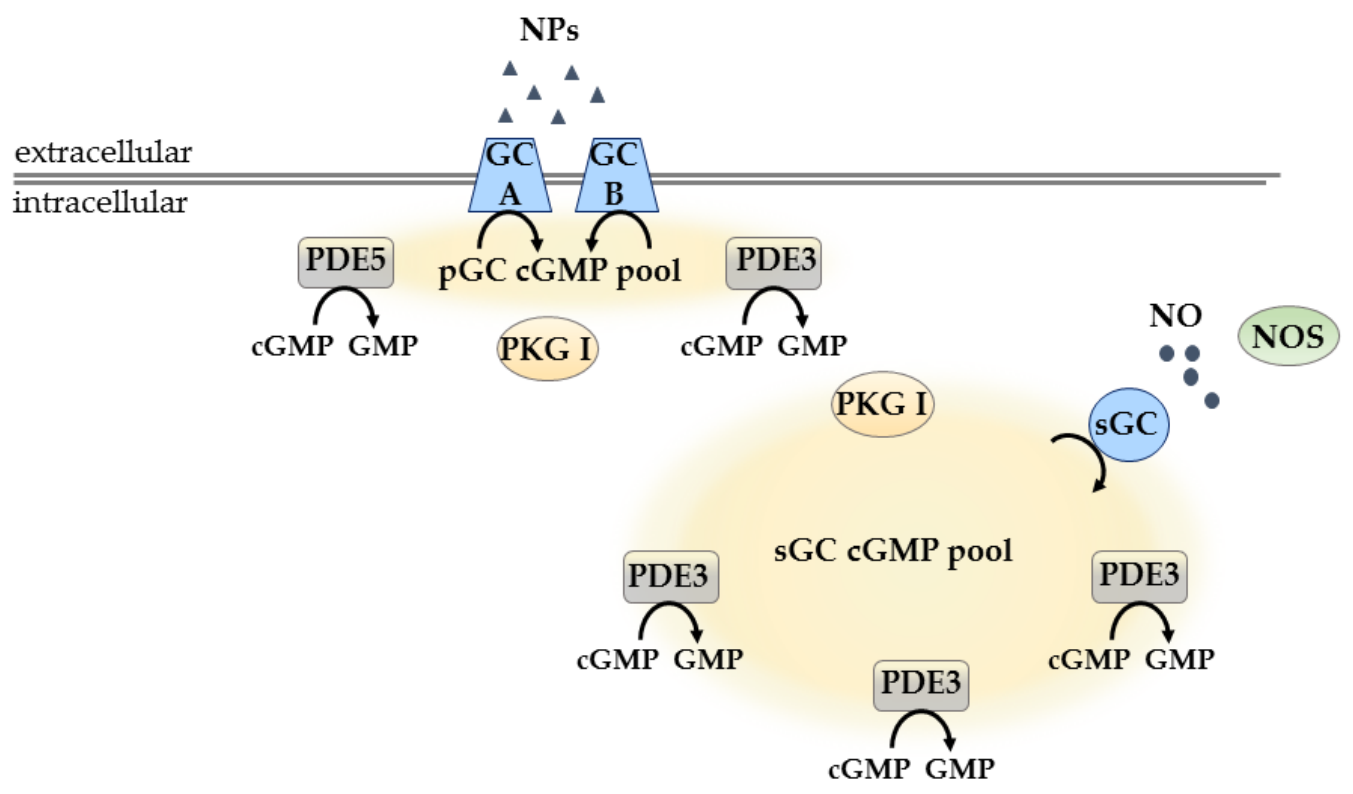

Figure 2. cGMP compartmentation in VSCMs. In VSMCs, there are two different cGMP pools: the pGC/cGMP pool, which is controlled by PDE5 and PDE3, and the sGC/cGMP pool, which is mainly regulated by PDE3. Black arrows indicate enzymatic activity.

In human VSMCs transduced with adenoviral vectors to express mutants of rat olfactory CNG channel-subunits, it could be shown by recording cGMP-gated currents $\left(\mathrm{I}_{\mathrm{CNG}}\right)$ that there are at least two separate cGMP pools: one localized next to plasma membrane and controlled by PDE5 and PDE3, and another localized to cytosol, regulated mainly by PDE3 [117] (Figure 2).

The development of transgenic cGMP FRET sensor mice, expressing the cytosolic cGi500 cGMP FRET sensor [82] in VSMCs offered new possibilities to study cGMP dynamics in these cells [83]. The authors created two different cGi500 mouse lines-a smooth-muscle specific transgenic line (SM22-cGi500 mice), expressing the cGi500 sensor under the control of the smooth-musclespecific SM22 $\alpha$ promoter, and the ubiquitous transgenic mouse line (R26-CAG-cGi500(L1) mice), where a targeted knock-in of the cGi500 sensor was done into the Rosa26 locus of Cre recombinase-activatable expression cassette driven by the ubiquitous cytomegalovirus early enhancer/chicken $\beta$-actin/ $\beta$-globin (CAG) promoter with a permanently active sensor transgene. FRET measurements in isolated VSMCs of both mouse lines showed that both CNP superfusion, and superfusion with the NO-releasing compound 2-( $N, N$-dethylamino)-diazenolate-2-oxide dethylammonium salt (DEA/NO) generated clearly detectable cGMP increases. Additionally, FRET measurements in VSMCs isolated form SM22-cGi500 mice showed that preincubation with the nonspecific PDE inhibitor 3-isobutyl-1-methylxanthine (IBMX) strongly potentiated NO-induced cGMP signals, whereas the selective PDE5 inhibitor sildenafil hat a comparatively weak effect. This indicates that cGMP levels in VSMCs are controlled by PDE5 and other PDEs. Additionally, differences in response to ANP and CNP were also shown. Whereas CNP stimulation leads to robust increase in cGMP concentrations, stimulation with ANP leads to weak but clearly detectable cGMP elevation [83] (Figure 2). 


\subsubsection{Compartmentation in Endothelial Cells}

While cGMP signaling has been extensively studied in VSCMs and CMs, studies in ECs are only at their beginning. In ECs, cGMP signaling is known to regulate cell motility, migration, and proliferation, which are vital to angiogenesis and vascular permeability [1].

The role of cGMP signaling on endothelial permeability has long been controversial. Surapisitchat et al. [118] hypothesized that the effect of cGMP on endothelial permeability is dependent on cGMP concentration. In their studies, the authors could show that in human umbilical vein endothelial cells (HUVECs), after slight elevation of cAMP with MPB-forskolin, low doses of either ANP or NO donors potentiated the inhibitory effect of MPB-forskolin on thrombin-induced permeability caused by inhibition of PDE3A at lower cGMP concentrations. However, this inhibitory effect was reversed at higher doses of ANP and NO donor because cGMP at higher concentrations activates PDE2A. These findings suggest that the result of cGMP signaling in endothelial cell permeability is highly dependent on the concentration of intracellular cGMP [118] (Figure 3).

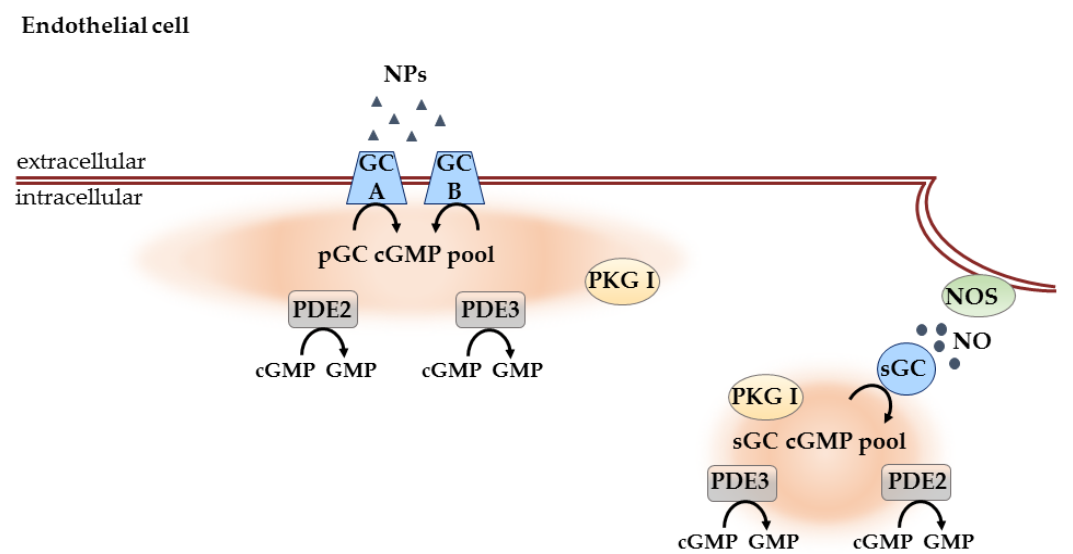

Figure 3. cGMP compartmentation in ECs. These cells also contain pGC and a sGC-associated cGMP pools. Both PDE2 and PDE3 are known to be involved in their regulation. The effect of cGMP signaling pathway is highly dependent on intracellular cGMP concentrations. sGC, PKG and PKA can be also localized to endothelial caveolae to regulate endothelial barrier function. Black arrows indicate enzymatic activity.

Some years later, another study was done by Chen et al. [119] which extended the previous findings by Surapisitchat et al. [118] that the effect of the cGMP signaling pathway in ECs is highly dependent on the intracellular cGMP concentrations. By doing real-time FRET measurements in HUVECs, the authors analyzed the effects on the regulation of submembrane versus cytosolic cAMP levels by ANP stimulation, using the membrane-targeted cAMP sensor pmEpac2-camps [112] or the cytosolic cAMP sensor Epac2-camps [120]. Whereas in resting HUVECs, ANP leads to an increase in submembrane and cytosolic cAMP levels indicating inhibition of the cGMP inhibited PDE3A, in HUVECs pretreated with TNF- $\alpha$ which induces PDE2 expression in these cells, ANP treatment mediated a mild but clear decrease of submembrane cAMP level (which was PDE2A mediated) but the effect of ANP on cytosolic cAMP level was unchanged. With these measurements, the authors could show that the cGMP/cAMP cross-talk is compartmentalized in ECs. [119] (Figure 3).

Another study provided further evidence of compartmentation of SGC, PKG and protein kinase A (PKA) in endothelial cell caveolae. It is known that, similar to CMs, in ECs, endothelial NO synthase (eNOS) is localized to caveolae. Using endothelium-intact aortic rings, relaxation of pre-contracted (with ACh) vessels by the SGC activator YC-1 and by 8-bromo-cGMP was impaired in the presence of methyl $\beta$-cyclodextrin - a chemical agent that disassembles caveolae by sequestering cholesterol from the membrane [27]. This suggests that sGC/cGMP/PKG pathway compartmentation in caveolae is required for the functional response of the vessels (Figure 3 ). 


\subsubsection{Compartmentation in Cardiac Fibroblasts}

CFs are the most abundant non-myocyte cell type in the heart. They help to maintain the extracellular matrix (ECM) of the heart by producing ECM components such as collagen and fibronectin, as well as promoting collagen degradation by secreting matrix metalloproteinases [7,121-123]. Even though CFs are the most abundant non-myocyte cell type in the heart, little is known about cGMP compartmentation in these cells.

A quantitative analysis of the cardiac fibroblast transcriptome revealed that CFs express components of the NO/cGMP signaling pathway-the $\alpha_{1}$ and $\beta_{1}$ sGC subunits, and PKG I. Inhibition of the proliferation of serum-treated CFs upon cGMP analog treatment indicates that PKG I mediates the inhibitory effects of the NO/cGMP pathway on CF growth [124].

One study was done to investigate the effect of NO production on $\beta$-adrenergic response in adult rat CFs. Upon immune response activation by IL- $1 \beta$ treatment, the inducible NO synthase (iNOS) is upregulated, which increases $\mathrm{NO}$ and therefore cGMP production to attenuate cAMP accumulation in response to isoproterenol or forskolin. By using of the broadband PDE inhibitor IBMX and the PDE2 specific PDE inhibitor erythro-2-(2-hydroxy-3-nonyl)adenine, the authors could show that cAMP attenuation is regulated via PDE2 stimulation caused by increased cGMP levels and not via an inhibition of adenylyl cyclase by NO or via stimulation of PKG [125].

An outside-in-crosstalk between the ECM protein fibronectin and GC-A has been also recently described. In cultured human CF, it could be shown that GC-A might transduce signals from ECM to CF. CFs plated on fibronectin demonstrated an increase in cGMP production to BNP compared to non-coated plates. This indicates that GC-A interacts with ECM components such as fibronectin to enhance BNP activation of cGMP [122]. It could be also shown that both Arg-Gly-Asp (RGD) attachment site containing ECM proteins and integrins may interact with BNP/GC-A to modulate cGMP generation [126].

\section{Conclusions}

During the last decades, a lot of research has been done on cGMP signaling in the cardiovascular system. However, there is still a plethora of unresolved questions. New imaging techniques for real-time cGMP detection offer great possibilities to better understand the role of subcellular compartmentation of cGMP signaling in living cells and tissues and until now, several interesting studies have been done investigating the role of subcellular cGMP compartmentation in the cardiovascular system.

Thus far, only a few studies focusing on subcellular cGMP compartmentation in adult CMs have been performed, mostly limited by the availability of highly sensitive live cells imaging techniques. It is known that in CMs there are at least two different cGMP pools: the NP/pGC/cGMP pool, controlled by PDE2 and PDE9, and the NO/sGC/cGMP pool, predominantly regulated by PDE5 and PDE3. One of the main downstream targets is PKG I, it is known to phosphorylate and inhibit PDE5. ANP/pGC stimulated PKG I can be recruited to the plasma membrane and is assumed to modulate GC-A activity. Several questions remain unresolved such as the role of GC distribution in the regulation of cGMP compartmentation. For such studies, the development of targeted cGMP FRET biosensors (similar to those which already exist for cAMP) would be very useful.

Studies in VSMCs showed the existence of two different cGMP pools: pGC/cGMP, controlled by PDE5 and PDE3, and SGC/cGMP, mainly regulated by PDE3. Thus far, most of the studies have been done using electrophysiological recordings of CNG channel activity, which are limited to the subsarcolemmal microdomains. In ECs, only a few studies have been done to show that the effect of cGMP signaling pathway is highly dependent on the intracellular cGMP concentrations. pGC- and a sGC-associated cGMP pool have been identified and shown to be regulated and PDE2 and PDE3. Recent reports suggest interesting PDE2/PDE3-mediated compartmentation of cGMP at the membrane vs. other subcellular locations which should be further address using FRET biosensors. 
Although new imaging techniques for real-time cGMP detection offer great possibilities to better understand the role of cGMP compartmentation, such studies remain challenging. Low cGMP concentration and complexity of subcellular microdomains require special efforts and the development of better techniques and biosensors, which is still ongoing. This is a challenging but important field of research since a better understanding of cGMP compartmentation in the cardiovascular system could offer novel pharmacological approaches for the treatment of multiple cardiovascular diseases.

Acknowledgments: The work of our laboratory is supported by the Deutsche Forschungsgemeinschaft (grant NI 1301/3-2 to Viacheslav O. Nikolaev), European Research Area Network on Cardiovascular Diseases (ERA-CVD) and the Gertraud und Heinz-Rose Stiftung.

Author Contributions: Nadja I. Bork and Viacheslav O. Nikolaev developed a concept and drafted the manuscript.

Conflicts of Interest: The authors declare no conflict of interest.

\begin{tabular}{|c|c|}
\hline $\mathrm{ACh}$ & Acetylcholine \\
\hline $\mathrm{AChR}$ & Acetylcholine receptor \\
\hline AMP & Adenosine monophosphate \\
\hline ANP & Atrial natriuretic peptide \\
\hline BNP & Brain natriuretic peptide \\
\hline CAG & Cytomegalovirus early enhancer/chicken $\beta$-actin $/ \beta$-globin \\
\hline cAMP & Adenosine monophosphate \\
\hline CF & Cardiac fibroblast \\
\hline cGMP & Cyclic guanosine $3^{\prime}, 5^{\prime}$-monophosphate \\
\hline $\mathrm{CM}$ & Cardiomyocyte \\
\hline $\mathrm{CNG}$ & Cyclic nucleotide gated channels \\
\hline $\mathrm{CNP}$ & C-type natriuretic peptide \\
\hline $\mathrm{DEA} / \mathrm{NO}$ & 2-(N,N-dethylamino)-diazenolate-2-oxide dethylammonium salt \\
\hline EC & Endothelial cell \\
\hline ECFP & Enhanced cyan fluorescent protein \\
\hline ECM & Extracellular matrix \\
\hline EDRF & Endothelium derived relaxation factor \\
\hline ELISA & Enzyme-linked immunoassay \\
\hline eNOS & Endothelial NO synthase \\
\hline EYFP & Enhanced yellow fluorescent protein \\
\hline FRET & Förster resonance energy transfer \\
\hline GC & Guanylyl cyclase \\
\hline GMP & Guanosine monophosphate \\
\hline GTP & Guanosine triphosphate \\
\hline HUVEC & Human umbilical vein endothelial cell \\
\hline IBMX & 3-isobutyl-1-methylxanthine \\
\hline $\mathrm{mAChR}$ & Muscarinic acetylcholine receptor \\
\hline iNOS & Inducible NO synthase \\
\hline nAChR & Nicotinic acetylcholine receptor \\
\hline $\mathrm{NO}$ & Nitric oxide \\
\hline NOS & NO synthase \\
\hline NP & Natriuretic peptide \\
\hline PDE & Phosphodiesterase \\
\hline pGC & Particulate guanylyl cyclase \\
\hline PKG & cGMP-dependent protein kinase \\
\hline PKG I & cGMP-dependent protein kinase type I \\
\hline PKG II & cGMP-dependent protein kinase type II \\
\hline RGD & Arg-Gly-Asp \\
\hline
\end{tabular}


$\begin{array}{ll}\text { sGC } & \text { Soluble guanylyl cyclase } \\ \text { VSMC } & \text { Vascular smooth muscle cell }\end{array}$

\section{References}

1. Tsai, E.J.; Kass, D.A. Cyclic GMP signaling in cardiovascular pathophysiology and therapeutics. Pharmacol. Ther. 2009, 122, 216-238. [CrossRef] [PubMed]

2. Weber, S.; Zeller, M.; Guan, K.; Wunder, F.; Wagner, M.; El-Armouche, A. PDE2 at the crossway between cAMP and cGMP signalling in the heart. Cell. Signal. 2017, 38, 76-84. [CrossRef] [PubMed]

3. Feil, R.; Lohmann, S.M.; de Jonge, H.; Walter, U.; Hofmann, F. Cyclic GMP-Dependent Protein Kinases and the Cardiovascular System. Circ. Res. 2003, 93, 907-916. [CrossRef] [PubMed]

4. Takimoto, E. Cyclic GMP-dependent signaling in cardiac myocytes. Circ. J. Off. J. Jpn. Circ. Soc. 2012, 76, 1819-1825. [CrossRef]

5. Ashman, D.F.; Lipton, R.; Melicow, M.M.; Price, T.D. Isolation of adenosine $3^{\prime}, 5^{\prime}$-monophosphate and guanosine 3',5'-monophosphate from rat urine. Biochem. Biophys. Res. Commun. 1963, 11, 330-334. [CrossRef]

6. Beavo, J.A.; Brunton, L.L. Cyclic nucleotide research-Still expanding after half a century. Nat. Rev. Mol. Cell Biol. 2002, 3, 710. [CrossRef] [PubMed]

7. Lukowski, R.; Krieg, T.; Rybalkin, S.D.; Beavo, J.; Hofmann, F. Turning on cGMP-dependent pathways to treat cardiac dysfunctions: Boom, bust, and beyond. Trends Pharmacol. Sci. 2014, 35, 404-413. [CrossRef] [PubMed]

8. Zhao, Y.; Vanhoutte, P.M.; Leung, S.W. Vascular nitric oxide: Beyond eNOS. J. Pharmacol. Sci. 2015, 129, 83-94. [CrossRef] [PubMed]

9. Kuhn, M. Endothelial actions of atrial and B-type natriuretic peptides. Br. J. Pharmacol. 2012, 166, 522-531. [CrossRef] [PubMed]

10. Baxter, G.F. Natriuretic peptides and myocardial ischaemia. Basic Res. Cardiol. 2004, 99, 90-93. [CrossRef] [PubMed]

11. Chinkers, M.; Garbers, D.L.; Chang, M.S.; Lowe, D.G.; Chin, H.M.; Goeddel, D.V.; Schulz, S. A membrane form of guanylate cyclase is an atrial natriuretic peptide receptor. Nature 1989, 338, 78-83. [CrossRef] [PubMed]

12. Takimoto, E.; Champion, H.C.; Li, M.; Belardi, D.; Ren, S.; Rodriguez, E.R.; Bedja, D.; Gabrielson, K.L.; Wang, Y.; Kass, D.A. Chronic inhibition of cyclic GMP phosphodiesterase 5A prevents and reverses cardiac hypertrophy. Nat. Med. 2005, 11, 214-222. [CrossRef] [PubMed]

13. Cerra, M.C.; Pellegrino, D. Cardiovascular cGMP-generating systems in physiological and pathological conditions. Curr. Med. Chem. 2007, 14, 585-599. [CrossRef] [PubMed]

14. Russwurm, M.; Wittau, N.; Koesling, D. Guanylyl cyclase/PSD-95 interaction: Targeting of the nitric oxide-sensitive $\alpha 2 \beta 1$ guanylyl cyclase to synaptic membranes. J. Biol. Chem. 2001, 276, 44647-44652. [CrossRef] [PubMed]

15. Montfort, W.R.; Wales, J.A.; Weichsel, A. Structure and Activation of Soluble Guanylyl Cyclase, the Nitric Oxide Sensor. Antioxid. Redox Signal. 2017, 26, 107-121. [CrossRef] [PubMed]

16. Moody, B.F.; Calvert, J.W. Emergent role of gasotransmitters in ischemia-reperfusion injury. Med. Gas. Res. 2011, 1, 3. [CrossRef] [PubMed]

17. Rastaldo, R.; Pagliaro, P.; Cappello, S.; Penna, C.; Mancardi, D.; Westerhof, N.; Losano, G. Nitric oxide and cardiac function. Life Sci. 2007, 81, 779-793. [CrossRef] [PubMed]

18. Saraiva, R.M.; Hare, J.M. Nitric oxide signaling in the cardiovascular system: Implications for heart failure. Curr. Opin. Cardiol. 2006, 21, 221-228. [CrossRef] [PubMed]

19. Kuhn, M. Structure, regulation, and function of mammalian membrane guanylyl cyclase receptors, with a focus on guanylyl cyclase-A. Circ. Res. 2003, 93, 700-709. [CrossRef] [PubMed]

20. Kuhn, M. Molecular Physiology of Membrane Guanylyl Cyclase Receptors. Physiol. Rev. 2016, 96, 751-804. [CrossRef] [PubMed]

21. Garbers, D.L.; Koesling, D.; Schultz, G. Guanylyl cyclase receptors. Mol. Biol. Cell 1994, 5, 1-5. [CrossRef] [PubMed]

22. Woodard, G.E.; Rosado, J.A. Natriuretic peptides in vascular physiology and pathology. Int. Rev. Cell Mol. Biol. 2008, 268, 59-93. [PubMed] 
23. Nakao, K.; Ogawa, Y.; Suga, S.; Imura, H. Molecular biology and biochemistry of the natriuretic peptide system. II: Natriuretic peptide receptors. J. Hypertens. 1992, 10, 1111-1114. [CrossRef] [PubMed]

24. Koller, K.J.; Lowe, D.G.; Bennett, G.L.; Minamino, N.; Kangawa, K.; Matsuo, H.; Goeddel, D.V. Selective activation of the B natriuretic peptide receptor by C-type natriuretic peptide (CNP). Science 1991, 252, 120-123. [CrossRef] [PubMed]

25. Zaccolo, M.; Movsesian, M.A. cAMP and cGMP Signaling Cross-Talk: Role of Phosphodiesterases and Implications for Cardiac Pathophysiology. Circ. Res. 2007, 100, 1569-1578. [CrossRef] [PubMed]

26. Evgenov, O.V.; Pacher, P.; Schmidt, P.M.; Hasko, G.; Schmidt, H.H.; Stasch, J.P. NO-independent stimulators and activators of soluble guanylate cyclase: Discovery and therapeutic potential. Nat. Rev. Drug. Discov. 2006, 5, 755-768. [CrossRef] [PubMed]

27. Linder, A.E.; McCluskey, L.P.; Cole, K.R., 3rd; Lanning, K.M.; Webb, R.C. Dynamic association of nitric oxide downstream signaling molecules with endothelial caveolin-1 in rat aorta. J. Pharmacol. Exp. Ther. 2005, 314, 9-15. [CrossRef] [PubMed]

28. Venema, R.C.; Venema, V.J.; Ju, H.; Harris, M.B.; Snead, C.; Jilling, T.; Dimitropoulou, C.; Maragoudakis, M.E.; Catravas, J.D. Novel complexes of guanylate cyclase with heat shock protein 90 and nitric oxide synthase. Am. J. Physiol. Heart Circ. Physiol. 2003, 285, H669-H678. [CrossRef] [PubMed]

29. Albuquerque, E.X.; Pereira, E.F.; Alkondon, M.; Rogers, S.W. Mammalian nicotinic acetylcholine receptors: From structure to function. Physiol. Rev. 2009, 89, 73-120. [CrossRef] [PubMed]

30. Karlin, A.; Cox, R.N.; Dipaola, M.; Holtzman, E.; Kao, P.N.; Lobel, P.; Wang, L.; Yodh, N. Functional domains of the nicotinic acetylcholine receptor. Ann. N. Y. Acad. Sci. 1986, 463, 53-69. [CrossRef] [PubMed]

31. Harvey, R.D.; Belevych, A.E. Muscarinic regulation of cardiac ion channels. Br. J. Pharmacol. 2003, 139, 1074-1084. [CrossRef] [PubMed]

32. Cooke, J.P.; Ghebremariam, Y.T. Endothelial nicotinic acetylcholine receptors and angiogenesis. Trends Cardiovasc. Med. 2008, 18, 247-253. [CrossRef] [PubMed]

33. Eglen, R.M. Overview of muscarinic receptor subtypes. Handb. Exp. Pharmacol. 2012, 3-28. [CrossRef]

34. Attina, T.M.; Oliver, J.J.; Malatino, L.S.; Webb, D.J. Contribution of the M3 muscarinic receptors to the vasodilator response to acetylcholine in the human forearm vascular bed. Br. J. Clin. Pharmacol. 2008, 66, 300-303. [CrossRef] [PubMed]

35. Eglen, R.M.; Reddy, H.; Watson, N.; Challiss, R.A. Muscarinic acetylcholine receptor subtypes in smooth muscle. Trends Pharmacol. Sci. 1994, 15, 114-119. [CrossRef]

36. Goutsouliak, V.; Wang, Y.; Cynader, M.S.; Rabkin, S.W. Visualization of muscarinic cholinergic receptors on chick cardiomyocytes and their involvement in phosphatidylcholine hydrolysis. Biochem. Cell Biol. 1997, 75, 127-136. [CrossRef] [PubMed]

37. Dvorakova, M.; Lips, K.S.; Bruggmann, D.; Slavikova, J.; Kuncova, J.; Kummer, W. Developmental changes in the expression of nicotinic acetylcholine receptor $\alpha$-subunits in the rat heart. Cell Tissue Res. 2005, 319, 201-209. [CrossRef] [PubMed]

38. Ignarro, L.J.; Buga, G.M.; Wood, K.S.; Byrns, R.E.; Chaudhuri, G. Endothelium-derived relaxing factor produced and released from artery and vein is nitric oxide. Proc. Natl. Acad. Sci. USA 1987, 84, 9265-9269. [CrossRef] [PubMed]

39. Furchgott, R.F.; Vanhoutte, P.M. Endothelium-derived relaxing and contracting factors. FASEB J. 1989, 3 , 2007-2018. [CrossRef] [PubMed]

40. Rapoport, R.M.; Murad, F. Agonist-induced endothelium-dependent relaxation in rat thoracic aorta may be mediated through cGMP. Circ. Res. 1983, 52, 352-357. [CrossRef] [PubMed]

41. Griffith, T.M.; Edwards, D.H.; Lewis, M.J.; Newby, A.C.; Henderson, A.H. The nature of endothelium-derived vascular relaxant factor. Nature 1984, 308, 645-647. [CrossRef] [PubMed]

42. Forstermann, U.; Mulsch, A.; Bohme, E.; Busse, R. Stimulation of soluble guanylate cyclase by an acetylcholine-induced endothelium-derived factor from rabbit and canine arteries. Circ. Res. 1986, 58, 531-538. [CrossRef] [PubMed]

43. Brodde, O.E.; Michel, M.C. Adrenergic and muscarinic receptors in the human heart. Pharmacol. Rev. 1999, 51, 651-690. [PubMed]

44. Jungen, C.; Scherschel, K.; Eickholt, C.; Kuklik, P.; Klatt, N.; Bork, N.; Salzbrunn, T.; Alken, F.; Angendohr, S.; Klene, C.; et al. Disruption of cardiac cholinergic neurons enhances susceptibility to ventricular arrhythmias. Nat. Commun. 2017, 8, 14155. [CrossRef] [PubMed] 
45. Mavropoulos, S.A.; Khan, N.S.; Levy, A.C.J.; Faliks, B.T.; Sison, C.P.; Pavlov, V.A.; Zhang, Y.; Ojamaa, K. Nicotinic acetylcholine receptor-mediated protection of the rat heart exposed to ischemia reperfusion. Mol. Med. 2017, 23, 120. [CrossRef] [PubMed]

46. Gileadi, O. Structures of soluble guanylate cyclase: Implications for regulatory mechanisms and drug development. Biochem. Soc. Trans. 2014, 42, 108-113. [CrossRef] [PubMed]

47. Lukowski, R.; Rybalkin, S.D.; Loga, F.; Leiss, V.; Beavo, J.A.; Hofmann, F. Cardiac hypertrophy is not amplified by deletion of cGMP-dependent protein kinase I in cardiomyocytes. Proc. Natl. Acad. Sci. USA 2010, 107, 5646-5651. [CrossRef] [PubMed]

48. Hofmann, F.; Bernhard, D.; Lukowski, R.; Weinmeister, P. cGMP regulated protein kinases (cGK). Handb. Exp. Pharmacol. 2009, 137-162. [CrossRef]

49. Lorenz, R.; Bertinetti, D.; Herberg, F.W. cAMP-Dependent Protein Kinase and cGMP-Dependent Protein Kinase as Cyclic Nucleotide Effectors. Handb. Exp. Pharmacol. 2017, 238, 105-122. [PubMed]

50. Kim, G.E.; Kass, D.A. Cardiac Phosphodiesterases and Their Modulation for Treating Heart Disease. Handb. Exp. Pharmacol. 2017, 243, 249-269. [PubMed]

51. Biel, M.; Michalakis, S. Cyclic nucleotide-gated channels. Handb. Exp. Pharmacol. 2009, 111-136. [CrossRef]

52. Kaupp, U.B.; Seifert, R. Cyclic nucleotide-gated ion channels. Physiol. Rev. 2002, 82, 769-824. [CrossRef] [PubMed]

53. Bradley, J.; Reisert, J.; Frings, S. Regulation of cyclic nucleotide-gated channels. Curr. Opin. Neurobiol. 2005, 15, 343-349. [CrossRef] [PubMed]

54. Bender, A.T.; Beavo, J.A. Cyclic nucleotide phosphodiesterases: Molecular regulation to clinical use. Pharmacol. Rev. 2006, 58, 488-520. [CrossRef] [PubMed]

55. Kokkonen, K.; Kass, D.A. Nanodomain Regulation of Cardiac Cyclic Nucleotide Signaling by Phosphodiesterases. Annu. Rev. Pharmacol. Toxicol. 2017, 57, 455-479. [CrossRef] [PubMed]

56. Brescia, M.; Zaccolo, M. Modulation of Compartmentalised Cyclic Nucleotide Signalling via Local Inhibition of Phosphodiesterase Activity. Int. J. Mol. Sci. 2016, 17, 1672. [CrossRef] [PubMed]

57. Conti, M.; Beavo, J. Biochemistry and physiology of cyclic nucleotide phosphodiesterases: Essential components in cyclic nucleotide signaling. Annu. Rev. Biochem. 2007, 76, 481-511. [CrossRef] [PubMed]

58. Lugnier, C. Cyclic nucleotide phosphodiesterase (PDE) superfamily: A new target for the development of specific therapeutic agents. Pharmacol. Ther. 2006, 109, 366-398. [CrossRef] [PubMed]

59. Degerman, E.; Belfrage, P.; Manganiello, V.C. Structure, localization, and regulation of cGMP-inhibited phosphodiesterase (PDE3). J. Biol. Chem. 1997, 272, 6823-6826. [CrossRef] [PubMed]

60. Lee, D.I.; Kass, D.A. Phosphodiesterases and cyclic GMP regulation in heart muscle. Physiology 2012, 27, 248-258. [CrossRef] [PubMed]

61. Miller, C.L.; Yan, C. Targeting cyclic nucleotide phosphodiesterase in the heart: Therapeutic implications. J. Cardiovasc. Transl. Res. 2010, 3, 507-515. [CrossRef] [PubMed]

62. Zhang, M.; Kass, D.A. Phosphodiesterases and cardiac cGMP: Evolving roles and controversies. Trends Pharmacol. Sci. 2011, 32, 360-365. [CrossRef] [PubMed]

63. Götz, K.; Sprenger, J.; Perera, R.K.; Steinbrecher, J.H.; Lehnart, S.E.; Kuhn, M.; Gorelik, J.; Balligand, J.-L.; Nikolaev, V.O. Transgenic Mice for Real Time Visualization of cGMP in Intact Adult Cardiomyocytes. Circ. Res. 2014. [CrossRef] [PubMed]

64. Sprenger, J.U.; Nikolaev, V.O. Biophysical techniques for detection of cAMP and cGMP in living cells. Int. J. Mol. Sci. 2013, 14, 8025-8046. [CrossRef] [PubMed]

65. Barsony, J.; Marx, S.J. Immunocytology on microwave-fixed cells reveals rapid and agonist-specific changes in subcellular accumulation patterns for cAMP or cGMP. Proc. Natl. Acad. Sci. USA 1990, 87, 1188-1192. [CrossRef] [PubMed]

66. Brooker, G.; Harper, J.F.; Terasaki, W.L.; Moylan, R.D. Radioimmunoassay of cyclic AMP and cyclic GMP. Adv. Cycl. Nucleotide Res. 1979, 10, 1-33.

67. Williams, C. cAMP detection methods in HTS: Selecting the best from the rest. Nat. Rev. Drug. Discov. 2004, 3, 125-135. [CrossRef] [PubMed]

68. Honda, A.; Adams, S.R.; Sawyer, C.L.; Lev-Ram, V.; Tsien, R.Y.; Dostmann, W.R. Spatiotemporal dynamics of guanosine $3^{\prime}, 5^{\prime}$-cyclic monophosphate revealed by a genetically encoded, fluorescent indicator. Proc. Natl. Acad. Sci. USA 2001, 98, 2437-2442. [CrossRef] [PubMed] 
69. Trivedi, B.; Kramer, R.H. Real-time patch-cram detection of intracellular cGMP reveals long-term suppression of responses to NO and muscarinic agonists. Neuron 1998, 21, 895-906. [CrossRef]

70. Goulding, E.H.; Tibbs, G.R.; Siegelbaum, S.A. Molecular mechanism of cyclic-nucleotide-gated channel activation. Nature 1994, 372, 369-374. [CrossRef] [PubMed]

71. Castro, L.R.; Verde, I.; Cooper, D.M.; Fischmeister, R. Cyclic guanosine monophosphate compartmentation in rat cardiac myocytes. Circulation 2006, 113, 2221-2228. [CrossRef] [PubMed]

72. Sharma, S.; Visweswariah, S.S. Illuminating Cyclic Nucleotides: Sensors for cAMP and cGMP and Their Application in Live Cell Imaging. J. Indian Inst. Sci. 2017, 97, 109-128. [CrossRef]

73. Kraft, A.E.; Nikolaev, V.O. FRET Microscopy for Real-Time Visualization of Second Messengers in Living Cells. In Light Microscopy: Methods and Protocols; Markaki, Y., Harz, H., Eds.; Springer: New York, NY, USA, 2017; pp. 85-90. [CrossRef]

74. Förster, T. Zwischenmolekulare Energiewanderung und Fluoreszenz. Annalen der Physik 1948, 437, 55-75. [CrossRef]

75. Miyawaki, A. Visualization of the Spatial and Temporal Dynamics of Intracellular Signaling. Dev. Cell 2003, 4, 295-305. [CrossRef]

76. Shrestha, D.; Jenei, A.; Nagy, P.; Vereb, G.; Szollosi, J. Understanding FRET as a research tool for cellular studies. Int. J. Mol. Sci. 2015, 16, 6718-6756. [CrossRef] [PubMed]

77. Nikolaev, V.O.; Gambaryan, S.; Lohse, M.J. Fluorescent sensors for rapid monitoring of intracellular cGMP. Nat. Methods 2006, 3, 23-25. [CrossRef] [PubMed]

78. Sato, M.; Hida, N.; Ozawa, T.; Umezawa, Y. Fluorescent indicators for cyclic GMP based on cyclic GMP-dependent protein kinase I $\alpha$ and green fluorescent proteins. Anal. Chem. 2000, 72, 5918-5924. [CrossRef] [PubMed]

79. Stangherlin, A.; Gesellchen, F.; Zoccarato, A.; Terrin, A.; Fields, L.A.; Berrera, M.; Surdo, N.C.; Craig, M.A.; Smith, G.; Hamilton, G.; et al. cGMP signals modulate cAMP levels in a compartment-specific manner to regulate catecholamine-dependent signaling in cardiac myocytes. Circ. Res. 2011, 108, 929-939. [CrossRef] [PubMed]

80. Herget, S.; Lohse, M.J.; Nikolaev, V.O. Real-time monitoring of phosphodiesterase inhibition in intact cells. Cell. Signal. 2008, 20, 1423-1431. [CrossRef] [PubMed]

81. Couto, A.; Oda, S.; Nikolaev, V.O.; Soltesz, Z.; de Bono, M. In vivo genetic dissection of O2-evoked cGMP dynamics in a Caenorhabditis elegans gas sensor. Proc. Natl. Acad. Sci. USA 2013, 110, E3301-E3310. [CrossRef] [PubMed]

82. Russwurm, M.; Mullershausen, F.; Friebe, A.; Jager, R.; Russwurm, C.; Koesling, D. Design of fluorescence resonance energy transfer (FRET)-based cGMP indicators: A systematic approach. Biochem. J. 2007, 407, 69-77. [CrossRef] [PubMed]

83. Thunemann, M.; Wen, L.; Hillenbrand, M.; Vachaviolos, A.; Feil, S.; Ott, T.; Han, X.; Fukumura, D.; Jain, R.K.; Russwurm, M.; et al. Transgenic mice for cGMP imaging. Circ. Res. 2013, 113, 365-371. [CrossRef] [PubMed]

84. Belge, C.; Hammond, J.; Dubois-Deruy, E.; Manoury, B.; Hamelet, J.; Beauloye, C.; Markl, A.; Pouleur, A.C.; Bertrand, L.; Esfahani, H.; et al. Enhanced expression of $\beta 3$-adrenoceptors in cardiac myocytes attenuates neurohormone-induced hypertrophic remodeling through nitric oxide synthase. Circulation 2014, 129, 451-462. [CrossRef] [PubMed]

85. Niino, Y.; Hotta, K.; Oka, K. Simultaneous Live Cell Imaging Using Dual FRET Sensors with a Single Excitation Light. PLoS ONE 2009, 4, e6036. [CrossRef] [PubMed]

86. Bhargava, Y.; Hampden-Smith, K.; Chachlaki, K.; Wood, K.C.; Vernon, J.; Allerston, C.K.; Batchelor, A.M.; Garthwaite, J. Improved genetically-encoded, FlincG-type fluorescent biosensors for neural cGMP imaging. Front. Mol. Neurosci. 2013, 6, 26. [CrossRef] [PubMed]

87. Nausch, L.W.; Ledoux, J.; Bonev, A.D.; Nelson, M.T.; Dostmann, W.R. Differential patterning of cGMP in vascular smooth muscle cells revealed by single GFP-linked biosensors. Proc. Natl. Acad. Sci. USA 2008, 105, 365-370. [CrossRef] [PubMed]

88. Beaulieu, P.; Cardinal, R.; De Lean, A.; Lambert, C. Direct chronotropic effects of atrial and C-type natriuretic peptides in anaesthetized dogs. Br. J. Pharmacol. 1996, 118, 1790-1796. [CrossRef] [PubMed]

89. Hirose, M.; Furukawa, Y.; Miyashita, Y.; Kurogouchi, F.; Nakajima, K.; Tsuboi, M.; Chiba, S. CNP causes receptor-mediated positive dromotropic effects in anesthetized dog hearts. Am. J. Physiol. 1998, 275, H717-H720. [CrossRef] [PubMed] 
90. Nir, A.; Zhang, D.F.; Fixler, R.; Burnett, J.C., Jr.; Eilam, Y.; Hasin, Y. C-type natriuretic peptide has a negative inotropic effect on cardiac myocytes. Eur. J. Pharmacol. 2001, 412, 195-201. [CrossRef]

91. Fixler, R.; Hasin, Y.; Eilam, Y.; Zhang, D.F.; Nir, A. Opposing effects of endothelin-1 on C-type natriuretic peptide actions in rat cardiomyocytes. Eur. J. Pharmacol. 2001, 423, 95-98. [CrossRef]

92. Brusq, J.M.; Mayoux, E.; Guigui, L.; Kirilovsky, J. Effects of C-type natriuretic peptide on rat cardiac contractility. Br. J. Pharmacol. 1999, 128, 206-212. [CrossRef] [PubMed]

93. Pierkes, M.; Gambaryan, S.; Boknik, P.; Lohmann, S.M.; Schmitz, W.; Potthast, R.; Holtwick, R.; Kuhn, M. Increased effects of $\mathrm{C}$-type natriuretic peptide on cardiac ventricular contractility and relaxation in guanylyl cyclase A-deficient mice. Cardiovasc. Res. 2002, 53, 852-861. [CrossRef]

94. Wollert, K.C.; Yurukova, S.; Kilic, A.; Begrow, F.; Fiedler, B.; Gambaryan, S.; Walter, U.; Lohmann, S.M.; Kuhn, M. Increased effects of C-type natriuretic peptide on contractility and calcium regulation in murine hearts overexpressing cyclic GMP-dependent protein kinase I. Br. J. Pharmacol. 2003, 140, 1227-1236. [CrossRef] [PubMed]

95. Neyses, L.; Vetter, H. Action of atrial natriuretic peptide and angiotensin II on the myocardium: Studies in isolated rat ventricular cardiomyocytes. Biochem. Biophys. Res. Commun. 1989, 163, 1435-1443. [CrossRef]

96. McCall, D.; Fried, T.A. Effect of atriopeptin II on Ca influx, contractile behavior and cyclic nucleotide content of cultured neonatal rat myocardial cells. J. Mol. Cell. Cardiol. 1990, 22, 201-212. [CrossRef]

97. Flesch, M.; Kilter, H.; Cremers, B.; Lenz, O.; Sudkamp, M.; Kuhn-Regnier, F.; Bohm, M. Acute effects of nitric oxide and cyclic GMP on human myocardial contractility. J. Pharmacol. Exp. Ther. 1997, 281, 1340-1349. [PubMed]

98. Kojda, G.; Kottenberg, K.; Nix, P.; Schluter, K.D.; Piper, H.M.; Noack, E. Low increase in cGMP induced by organic nitrates and nitrovasodilators improves contractile response of rat ventricular myocytes. Circ. Res. 1996, 78, 91-101. [CrossRef] [PubMed]

99. Weyrich, A.S.; Ma, X.L.; Buerke, M.; Murohara, T.; Armstead, V.E.; Lefer, A.M.; Nicolas, J.M.; Thomas, A.P.; Lefer, D.J.; Vinten-Johansen, J. Physiological concentrations of nitric oxide do not elicit an acute negative inotropic effect in unstimulated cardiac muscle. Circ. Res. 1994, 75, 692-700. [CrossRef] [PubMed]

100. Nawrath, H.; Baumner, D.; Rupp, J.; Oelert, H. The ineffectiveness of the NO-cyclic GMP signaling pathway in the atrial myocardium. Br. J. Pharmacol. 1995, 116, 3061-3067. [CrossRef] [PubMed]

101. Wegener, J.W.; Godecke, A.; Schrader, J.; Nawrath, H. Effects of nitric oxide donors on cardiac contractility in wild-type and myoglobin-deficient mice. Br. J. Pharmacol. 2002, 136, 415-420. [CrossRef] [PubMed]

102. Dittrich, M.; Jurevicius, J.; Georget, M.; Rochais, F.; Fleischmann, B.; Hescheler, J.; Fischmeister, R. Local response of L-type $\mathrm{Ca}(2+)$ current to nitric oxide in frog ventricular myocytes. J. Physiol. 2001, 534, 109-121. [CrossRef] [PubMed]

103. Fischmeister, R.; Castro, L.R.; Abi-Gerges, A.; Rochais, F.; Jurevicius, J.; Leroy, J.; Vandecasteele, G. Compartmentation of cyclic nucleotide signaling in the heart: The role of cyclic nucleotide phosphodiesterases. Circ. Res. 2006, 99, 816-828. [CrossRef] [PubMed]

104. Castro, L.R.; Schittl, J.; Fischmeister, R. Feedback control through cGMP-dependent protein kinase contributes to differential regulation and compartmentation of cGMP in rat cardiac myocytes. Circ. Res. 2010, 107, 1232-1240. [CrossRef] [PubMed]

105. Airhart, N.; Yang, Y.F.; Roberts, C.T., Jr.; Silberbach, M. Atrial natriuretic peptide induces natriuretic peptide receptor-cGMP-dependent protein kinase interaction. J. Biol. Chem. 2003, 278, 38693-38698. [CrossRef] [PubMed]

106. Stratton, R.C.; Squires, P.E.; Green, A.K. ANP stimulates hepatocyte Ca2+ efflux via plasma membrane recruitment of PKGI $\alpha$. Biochem. Biophys. Res. Commun. 2008, 368, 965-970. [CrossRef] [PubMed]

107. Takimoto, E.; Belardi, D.; Tocchetti, C.G.; Vahebi, S.; Cormaci, G.; Ketner, E.A.; Moens, A.L.; Champion, H.C.; Kass, D.A. Compartmentalization of cardiac $\beta$-adrenergic inotropy modulation by phosphodiesterase type 5. Circulation 2007, 115, 2159-2167. [CrossRef] [PubMed]

108. Nagayama, T.; Zhang, M.; Hsu, S.; Takimoto, E.; Kass, D.A. Sustained soluble guanylate cyclase stimulation offsets nitric-oxide synthase inhibition to restore acute cardiac modulation by sildenafil. J. Pharmacol. Exp. Ther. 2008, 326, 380-387. [CrossRef] [PubMed]

109. Lee, D.I.; Vahebi, S.; Tocchetti, C.G.; Barouch, L.A.; Solaro, R.J.; Takimoto, E.; Kass, D.A. PDE5A suppression of acute $\beta$-adrenergic activation requires modulation of myocyte $\beta$-3 signaling coupled to PKG-mediated troponin I phosphorylation. Basic Res. Cardiol. 2010, 105, 337-347. [CrossRef] [PubMed] 
110. Lee, D.I.; Zhu, G.; Sasaki, T.; Cho, G.-S.; Hamdani, N.; Holewinski, R.; Jo, S.-H.; Danner, T.; Zhang, M.; Rainer, P.P.; et al. Phosphodiesterase 9A controls nitric-oxide-independent cGMP and hypertrophic heart disease. Nature 2015, 519, 472-476. [CrossRef] [PubMed]

111. Perera, R.K.; Sprenger, J.U.; Steinbrecher, J.H.; Hubscher, D.; Lehnart, S.E.; Abesser, M.; Schuh, K.; El-Armouche, A.; Nikolaev, V.O. Microdomain switch of cGMP-regulated phosphodiesterases leads to ANP-induced augmentation of $\beta$-adrenoceptor-stimulated contractility in early cardiac hypertrophy. Circ. Res. 2015, 116, 1304-1311. [CrossRef] [PubMed]

112. Sprenger, J.U.; Perera, R.K.; Steinbrecher, J.H.; Lehnart, S.E.; Maier, L.S.; Hasenfuss, G.; Nikolaev, V.O. In vivo model with targeted cAMP biosensor reveals changes in receptor-microdomain communication in cardiac disease. Nat. Commun. 2015, 6, 6965. [CrossRef] [PubMed]

113. Morgado, M.; Cairrão, E.; Santos-Silva, A.J.; Verde, I. Cyclic nucleotide-dependent relaxation pathways in vascular smooth muscle. Cell. Mol. Life Sci. 2012, 69, 247-266. [CrossRef] [PubMed]

114. Sausbier, M.; Schubert, R.; Voigt, V.; Hirneiss, C.; Pfeifer, A.; Korth, M.; Kleppisch, T.; Ruth, P.; Hofmann, F. Mechanisms of NO/cGMP-Dependent Vasorelaxation. Circ. Res. 2000, 87, 825-830. [CrossRef] [PubMed]

115. Murad, F. Regulation of Cytosolic Guanylyl Cyclase by Nitric Oxide: The NO-Cyclic GMP Signal Transduction System. In Advances in Pharmacology; Murad, F., Ed.; Academic Press: Cambridge, MA, USA, 1994; Volume 26, pp. 19-33.

116. Piggott, L.A.; Hassell, K.A.; Berkova, Z.; Morris, A.P.; Silberbach, M.; Rich, T.C. Natriuretic peptides and nitric oxide stimulate cGMP synthesis in different cellular compartments. J. Gen. Physiol. 2006, 128, 3-14. [CrossRef] [PubMed]

117. Feiteiro, J.; Verde, I.; Cairrao, E. Cyclic guanosine monophosphate compartmentation in human vascular smooth muscle cells. Cell. Signal. 2016, 28, 109-116. [CrossRef] [PubMed]

118. Surapisitchat, J.; Jeon, K.I.; Yan, C.; Beavo, J.A. Differential regulation of endothelial cell permeability by cGMP via phosphodiesterases 2 and 3. Circ. Res. 2007, 101, 811-818. [CrossRef] [PubMed]

119. Chen, W.; Spitzl, A.; Mathes, D.; Nikolaev, V.O.; Werner, F.; Weirather, J.; Spiranec, K.; Rock, K.; Fischer, J.W.; Kammerer, U.; et al. Endothelial Actions of ANP Enhance Myocardial Inflammatory Infiltration in the Early Phase After Acute Infarction. Circ. Res. 2016, 119, 237-248. [CrossRef] [PubMed]

120. Nikolaev, V.O.; Gambaryan, S.; Engelhardt, S.; Walter, U.; Lohse, M.J. Real-time monitoring of the PDE2 activity of live cells: Hormone-stimulated cAMP hydrolysis is faster than hormone-stimulated cAMP synthesis. J. Biol. Chem. 2005, 280, 1716-1719. [CrossRef] [PubMed]

121. MacKenna, D.; Summerour, S.R.; Villarreal, F.J. Role of mechanical factors in modulating cardiac fibroblast function and extracellular matrix synthesis. Cardiovasc. Res. 2000, 46, 257-263. [CrossRef]

122. Huntley, B.K.; Sandberg, S.M.; Noser, J.A.; Cataliotti, A.; Redfield, M.M.; Matsuda, Y.; Burnett, J.C., Jr. BNP-induced activation of CGMP in human cardiac fibroblasts: Interactions with fibronectin and natriuretic peptide receptors. J. Cell. Physiol. 2006, 209, 943-949. [CrossRef] [PubMed]

123. Souders, C.A.; Bowers, S.L.K.; Baudino, T.A. Cardiac Fibroblast. Circ. Res. 2009, 105, 1164. [CrossRef] [PubMed]

124. Smolenski, A.; Schultess, J.; Danielewski, O.; Garcia Arguinzonis, M.I.; Thalheimer, P.; Kneitz, S.; Walter, U.; Lohmann, S.M. Quantitative analysis of the cardiac fibroblast transcriptome-Implications for NO/cGMP signaling. Genomics 2004, 83, 577-587. [CrossRef] [PubMed]

125. Gustafsson, Å.B.; Brunton, L.L. Attenuation of cAMP accumulation in adult rat cardiac fibroblasts by IL-1 $\beta$ and NO: Role of cGMP-stimulated PDE2. Am. J. Physiol. Cell Physiol. 2002, 283, C463-C471. [CrossRef] [PubMed]

126. Huntley, B.K.; Ichiki, T.; Sangaralingham, S.J.; Chen, H.H.; Burnett, J.C., Jr. B-type natriuretic peptide and extracellular matrix protein interactions in human cardiac fibroblasts. J. Cell. Physiol. 2010, 225, 251-255. [CrossRef] [PubMed]

(C) 2018 by the authors. Licensee MDPI, Basel, Switzerland. This article is an open access article distributed under the terms and conditions of the Creative Commons Attribution (CC BY) license (http:/ / creativecommons.org/licenses/by/4.0/). 